\section{Allelopathic Effects of Pinus halepensis Needles on Turfgrasses and Biosensor Plants}

\author{
Panayiotis A. Nektarios ${ }^{1}$ \\ Department of Floriculture and Landscape Architecture, Agricultural University \\ of Athens, 75, Iera Odos, 118 55, Athens, Greece
}

Garyfalia Economou ${ }^{2}$ and Christos Avgoulas ${ }^{3}$

Department of Agronomy, Agricultural University of Athens, 75, Iera Odos, 118 55, Athens, Greece

Additional index words. Festuca arundinacea, Cynodon dactylon, Avena sativa, Lemna minor, inhibition, phytotoxic compounds, bioassay

\begin{abstract}
Fresh, senesced, and decaying pine needles from Pinus halepensis were evaluated for their allelopathic potential on Festuca arundinacea, Cynodon dactylon and the biosensor plants Avena sativa and Lemna minor through in vivo and in vitro studies. The in vivo study was performed in growth chambers, using 6,12 , and $18 \mathrm{~g}$ of pine needle tissue mixed with screened perlite as a substrate. The effects of the different pine needle types were evaluated by determining the total root length, total root surface, root dry weight, total shoot length, total shoot surface, and shoot dry weight. The in vitro study was performed in Petri dishes where seeds from each species were subjected to an increasing concentration of pine needle extract. The extracts were obtained from pine needle ground tissue that was diluted with water and either shacked at room temperature or placed in water bath at $40{ }^{\circ} \mathrm{C}$ for $24 \mathrm{~h}$. The evaluation of the allelopathic potential was performed with the determination of radicle length. The allelopathic potential of the pine needle tissues was confirmed with bioassays using oat (A. sativa) and duckweed ( $L$. minor). The results strongly suggested the allelopathic potential of the pine needle tissue, being more pronounced in the fresh, moderate in the senesced, and low in the decaying pine needles. The allelopathic substances were species-specific, and the inhibition resistance of the species tested followed the order $F$. arundinacea $>C$. dactylon $>A$. sativa. The inhibition of the $L$. minor suggested that the water soluble phytotoxic compounds were inhibitors of Photosystem II.
\end{abstract}

Plants produce many compounds that have no apparent metabolic, physiological, or structural role for the producer. These secondary metabolites might exhibit allelopathic effects and influence other organisms in the vicinity of the producer (Rice, 1984). In many cases, allelochemicals function as biochemical defence mechanisms or possess insecticidal, repellent, antifeedant, and antimicrobial activities (Grainge and Ahmed, 1988; Peterson et al., 1989).

In turfgrasses, allelopathy has been investigated as an interactive mechanism to explain competition between species (Lickfeldt et al., 2001). Brede (1991) was unable to determine allelopathic inhibitory action when leachate collected from a Poa annua putting green was applied onto bentgrass (Agrostis stolonifera ssp. palustris Huds.). In contrast, Buta et al. (1987) found different degrees of lettuce seedling growth inhibition when seed leachate from various turfgrasses was applied. Tall fescue (Festuca arundinacea Schreb.) has been found to exhibit allelopathic effects on birdsfoot tre-

Received for publication 19 Dec. 2003. Accepted for publication 25 June 2004. The authors wish to thank Susan Coward for her help in improving the manuscript.

${ }^{1}$ Assistant professor

${ }^{2}$ Lecturer.

${ }^{3}$ Professor. trees. Wilt et al. (1993a) found several volatile monoterpene hydrocarbons in the understory litter of P. monophylla Torr. \& Frem., which might act as phytotoxins. The monoterpene concentration was higher in fresh, remained relatively high in senesced, but diminished in the decaying needles of the litter material (Wilt et al., 1993b). Therefore, the aim of the present study is 1) to investigate the allelochemical characteristics of $P$. halepensis L. and to evaluate the allelopathic activity of pine tissues on the growth and development of $F$. arundinacea, C. dactylon, and A. sativa; 2) to determine the toxicity of the pine needle extracts received at different temperatures to the development of the above-mentioned turfgrass species; and 3) to determine the toxicity potential and characterize the aqueous extracts of the pine needles based on their inhibition effect on plant biosensors.

\section{Materials and Methods}

To evaluate the allelopathic potential of pine needles, three studies were performed:

Study I: Pine needle effects on plant growth. The study was performed in growth chambers with the use of small plastic pots ( $70 \mathrm{~mm}$ ID and $110 \mathrm{~mm}$ high), filled with sieved perlite (Isocon S.A., Athens, Greece) having a uniform particle distribution ( 0.5 to $1.0 \mathrm{~mm}$ ). Pine needles were collected from $P$. halepensis trees found in the area of Ilioupoli, a suburb of Athens, Greece. For the purposes of allelopathic assessment, 3 different physiological stages of the pine needles were used: 1) fresh pine needles (F) were collected from the pine trees; 2 ) senesced (S) pine needles, which had a yellowish color, were collected from the top of the thatch layer that was formed under the canopy of the trees, and 3) decaying (D) pine needles having a dark grey color were collected from the bottom of the thatch layer. The pine needles were cut into $5-\mathrm{mm}$ segments and placed at $-18{ }^{\circ} \mathrm{C}$ for $7 \mathrm{~d}$. The frozen tissues were incorporated in the perlite substrate at 3 different rates namely 6,12 , and $18 \mathrm{~g}$ of fresh weight per pot. The pots were then seeded either with tall fescue (F. arundinacea 'Tomahawk'), bermudagrass (C. dactylon 'Bluemuda'), or oat (A. sativa) at a rate of 20,20, and 3 seeds per pot, respectively. Oat was included in this study since it has been used extensively in allelopathy research as the receiver plant to test compounds released by a donor plant. Oat seeds germinate evenly, resulting in a uniform and rapid plant growth that enables qualification of biological response in plants. In addition, oat biotest is considered as a sensitive and easily facilitated method (Rice, 1984).

The seeded pots were placed in the growth chamber with a constant temperature of $24^{\circ} \mathrm{C}$ for tall fescue and oat and $30^{\circ} \mathrm{C}$ for bermudagrass. All pots were irrigated with deionised water, and artificial light was supplied with a photoperiod of 16 to $8 \mathrm{~h}$ light and dark, respectively. The seedlings were fertilized with foliar fertilizer (Nutrileaf 20-20-20; Miller, Hanover, Pa.) at a rate of $2.5 \mathrm{~g} \cdot \mathrm{L}^{-1}$ at weekly intervals after the emergence of the second leaf. The seedlings were destructively sampled 12,43 , and $31 \mathrm{~d}$ 
after seeding oat, tall fescue, and bermudagrass, respectively. The growth parameters that were measured included 1) total root length, 2) total root surface, 3) root dry weight, 4) total shoot length, 5) total leaf area, and 6) shoot dry weight. To determine total root length and total root surface, perlite was carefully washed off, and the remaining roots were stained with $0.1 \%$ trypan blue FAA staining solution $(10 \%$ formalin : $50 \%$ ethanol : 5\% acetic acid (by volume), respectively) following the procedure described by Kokko et al. (1993). The stained roots were scanned with a flat-bed scanner at 600-dpi analysis and saved as black and white images for analysis using the specialized software Delta-T SCAN Image Analysis (Delta-T Devices Ltd., Cambridge, U.K.). Total shoot length and leaf area were determined with the same methodology without using the staining solution. Each treatment had four replicates arranged in a completely randomized design.

Study II: Pine needle extract bioassays. In vitro bioassay tests were used to determine the inhibitory potential of each pine needle type on tall fescue and on bermudagrass root growth. Pine needles were collected in the same manner as described in Study I. The three different pine needle types (F, S, and D) were oven-dried at $75^{\circ} \mathrm{C}$ for $48 \mathrm{~h}$ and then ground. Eighty grams of each ground tissue were diluted in $400 \mathrm{~mL}$ of deionized water and then treated using one of the following two methods: 1 ) by shaking (170 $\mathrm{rpm}$ ) for $24 \mathrm{~h}$ at room temperature, and 2) by placing the mixture for $24 \mathrm{~h}$ in a water bath at $40^{\circ} \mathrm{C}$. The mixtures were then filtered through Whatman No. 42 filter paper and diluted to the following concentrations: $200,50,12.5,3.125$, and $1.5625 \mathrm{~g}$ of pine needle extract/L.

The aqueous dilutions of the needle extracts were bioassayed on tall fescue ( $F$. arundinacea 'Tomahawk') and bermudagrass ( $C$. dactylon 'Bluemuda') seeds. Twenty seeds from each turfgrass species were placed on a filter paper (Whatman No. 42) in sterilized 90 mm-diameter Petri dishes. Each Petri dish received 3 $\mathrm{mL}$ of the corresponding extract concentration while distilled water was used as the control. The Petri dishes were then sealed with Parafilm and placed in a dark growth chamber at $25^{\circ} \mathrm{C}$ and $30{ }^{\circ} \mathrm{C}$ for tall fescue and bermudagrass, respectively. Treatments were arranged in a completely randomized design with four replications. Radicle elongation was measured $11 \mathrm{~d}$ after seeding for both tall fescue and bermudagrass, and seeds that did not germinate were considered to have a radicle length of 0 $\mathrm{mm}$. Inhibitory concentrations needed to inhibit radicle growth to $50 \%$ of control radicle growth $\left(\mathrm{I}_{50}\right.$ value) were calculated using a log-probit analysis (Statistica, Statsoft, Inc., Tulsa, Okla.) and used as an index of the extract inhibitory activity (Finney, 1962, 1978).

Study III: Pine needle extract effects on plant biosensors. A similar procedure as in Study II was followed for the oat, which was used as a plant biosensor due to its sensitivity to allelopathic compounds. Five oat seeds were placed on filter paper in each Petri dish and $3 \mathrm{~mL}$ from each of the five above-mentioned pine needle extract concentrations were added, while distilled water was used as the control.
The Petri dishes were then sealed with Parafilm and placed in a dark growth chamber at $25^{\circ} \mathrm{C}$. Treatments were arranged in a completely randomized design with four replications. Radicle elongation of oat seeds was measured $8 \mathrm{~d}$ after seeding, using the same approach that was outlined in Study II, and seeds that did not germinate were considered to have a radicle length of $0 \mathrm{~mm}$. Data were typically expressed as a percentage of the radicle elongation of the control. The dose needed to inhibit oat radicle growth to $50 \%$ of control radicle growth $\left(\mathrm{I}_{50}\right.$ value) was determined from dose-response bioassays (Finney, 1962, 1978) using Statistica software.

The same extracts were tested via another bioassay using Lemna minor L., a duckweed species, as a test plant. The bioassays were conducted in 125-mL Erlenmeyer flasks with $200 \mathrm{mg}$ frond cluster of duckweed. The flasks were incubated at $25^{\circ} \mathrm{C}$ for $7 \mathrm{~d}$ and the reduction in the duckweed fresh weight was recorded. The duckweed plants of the present study were obtained from a natural population maintained by the Department of Floriculture and Landscape Architecture at the Agricultural University of Athens under greenhouse conditions. Lemna minor has been used in several allelopathic studies (Einhellig et al., 1985; Olofsdotter et al., 1995; Environmental test methods and guidelines, 1996) since the bioassay is sensitive and reliable especially at the first steps of a screening procedure. In general, duckweed species are highly sensitive to chemicals that inhibit the function of Photosystem II, and their response by chlorosis is readily measurable through the drastic decrease in their fresh weight (Einhellig et al., 1985; Leather and Einhellig, 1985; Olofsdotter et al., 1995). Based on the sensitivity of the duckweed species on phytotoxic substances, the Office of Prevention, Pesticides, and toxic Substances of the United States Environmental Protection Agency developed test guidelines for the use of the fresh water aquatic plants $L$. gibba and L. minor on the evaluation of the phytotoxicity potential of chemicals, pesticides, and toxic substances (Environmental Test Methods and Guidelines, 1996).

\section{Results and Discussion}

Study I: Pine needle effects on plant growth parameters. The incorporation of pine needles into the perlite substrate reduced growth and development of tall fescue and bermudagrass, thus suggesting that toxic compounds were released from the needle tissue. Growth inhibition was dependent on the type of pine needle and it was proportional to the incorporation rate. More specifically, the greatest reduction in root and shoot growth was observed in both turfgrass species from the fresh needle tissue (Tables 1 and 2). The senesced pine needles resulted in moderate and the decaying in low growth inhibition except in the case of bermudagrass root growth, which was reduced more in decaying rather than in senesced pine needles $(30.4 \%$ and $23.4 \%$ reduction of total root length, respectively).

Within each pine needle type, the shoot and the root growth inhibition increased proportionally with the needle mass that was incorporated in the substrate. Therefore, the greatest reduction was observed at the high incorporation rate (18 g/pot) of the fresh needle tissue for all the growth parameters monitored.

However, differences between the two turfgrass species were observed. It was noticed that in tall fescue the growth parameters that were mostly affected by the high incorporation rate of the fresh needles were the total root surface, the root dry weight, and the total leaf area $(49.7 \%, 52.9 \%$, and $52.6 \%$ growth reduction compared to the control, respectively). Total root surface and total leaf area were also subjected to the highest inhibition in bermudagrass (48.8\% and $69.5 \%$ growth reduction compared to the control, respectively) while root dry weight was not severely reduced $(28.2 \%$ growth reduction compared to the control). Therefore, total root surface and total leaf area were used as the most sensitive and appropriate turfgrass growth parameters to compare the allelopathic effects of pine needles.

Differences between the two turfgrass species were also observed concerning their tolerance to the tested needle types. Tall fescue root growth was only slightly hindered by the incorporation of decaying pine needles whereas bermudagrass root growth was significantly reduced $(19.8 \%$ and $41.7 \%$ reduction of total root surface compared to the control, respectively). In contrast, there was a similar reduction in root growth in senesced pine needles for both tall fescue and bermudagrass $(37.6 \%$ and $35.5 \%$ reduction of total root surface, respectively). For the fresh pine needles, root growth parameters were similar for both turfgrass species (48.8\% and $49.7 \%$ reduction of total root surface for tall fescue and bermudagrass, respectively) except for root dry weight, which was severely inhibited in tall fescue (52.9\% reduction) but only moderately so in bermudagrass ( $28.2 \%$ reduction).

Total leaf area in bermudagrass was significantly restricted in fresh, senesced, and decaying pine needles $(69.5 \%, 51.8 \%$, and $35.2 \%$ reduction compared to the control, respectively), indicating sensitivity of the specific species for this parameter. Tall fescue shoot growth was affected less, exhibiting only moderate total leaf area reduction in decaying pine needles (19.4\% reduction of total leaf area compared to the control), which increased in senesced and fresh pine needles $(35.8 \%$ and $52.6 \%$ reduction of total leaf area compared to the control, respectively).

Oat was verified as a sensitive bioindicator, since its root and shoot growth were significantly inhibited with all needle types (Table 3). Similarly to the previous observations, the parameters that exhibited the highest reduction compared to the control were total root surface, root dry weight, and total leaf area $(83.6 \%, 80.3 \%$, and $75.1 \%$ reduction, respectively compared to the control when fresh pine needles were incorporated at the rate of $18 \mathrm{~g} / \mathrm{pot}$ ). Oat root growth inhibition was more severe compared to shoot growth, which is in accordance with the findings of Leather and Einhellig (1985) and Olofsdotter 
et al. (1995). From Study I, it was demonstrated that inhibitory compounds existed within the pine needle tissue and that these compounds were more phytotoxic in the fresh rather than the senesced or decaying pine needles (Wilt et al., 1993b).

Study II: Pine needle extract bioassays. Pine needle extracts exhibited toxic effects that influenced germination and radicle elongation of both turfgrass species. The inhibition depended on the type of the pine needles, the extraction method of the ground pine needles, the concentration of the extract, and the turfgrass species.

More specifically, in tall fescue the inhibition of the radicle elongation was reduced only by fresh needle extract in $40{ }^{\circ} \mathrm{C}$ (Table 4). The warm-temperature $\left(40{ }^{\circ} \mathrm{C}\right)$ extraction of the fresh pine needles resulted in inhibition with an estimate rate $\mathrm{I}_{50}=38.0 \mathrm{~g}$ of fresh pine needle extract/L required to reduce the radicle length by $50 \%$. In contrast, the room-temperature extraction of the fresh pine needles did not inhibit germination or radicle elongation, indicating that the toxic substances were released more readily by the warm-temperature extraction (Table 4). Concentration increase of the senesced and decaying needle extractions resulted in radicle length inhibition which was minimal compared with the inhibitory effect of the fresh needles. Differences between the two extraction methods were not pronounced concerning the senesced and the decaying needle extractions. These results are in accordance with the findings of Patrick et al. (1963) and Cuenzi et al. (1967), both of which demonstrated that the toxic effect of plant residues generally decreased as decomposition progressed. However, Chung and Miller (1995) found that more water-soluble toxic substances were released from decomposing alfalfa tissue, a fact which was attributed to the formation of toxic chemicals by the microorganisms during residue decomposition.

Bermudagrass was found to be much more sensitive to the fresh and senesced pine needle extracts compared to the tall fescue (Tables 4 and 5). The estimated $I_{50}$ for bermudagrass radicle length inhibition was about 9 times lower compared with the value obtained for the tall fescue concerning the warm-temperature fresh-pine needle extraction treatment (Tables 4 and 5). Similarly, bermudagrass exhibited a much higher inhibition by the senesced pine needle extracts compared to tall fescue (Tables 4 and 5) demonstrating further the strong phytotoxic action of the substances that were included within the fresh and the

Table 1. Festuca arundinacea root and shoot characteristics as affected by pine needle type (control, decaying, senesced, fresh) and the concentration of the incorporated tissue. Values are the means of four replications and means that differ significantly using Tukey-Kramer (HSD) at a probability level $P \leq 0.05$ are noted with different letters.

\begin{tabular}{|c|c|c|c|c|c|c|c|}
\hline $\begin{array}{l}\text { Pine } \\
\text { needle } \\
\text { type }\end{array}$ & $\begin{array}{c}\text { Pine } \\
\text { needle } \\
\text { tissue } \\
\text { (g/pot) }\end{array}$ & $\begin{array}{l}\text { Total } \\
\text { root } \\
\text { length } \\
(\mathrm{mm})\end{array}$ & $\begin{array}{c}\text { Total } \\
\text { root } \\
\text { surface } \\
\left(\mathrm{mm}^{2}\right)\end{array}$ & $\begin{array}{l}\text { Root } \\
\text { dry } \\
\text { wt } \\
(\mathrm{mg})\end{array}$ & $\begin{array}{l}\text { Total } \\
\text { shoot } \\
\text { length } \\
(\mathrm{mm})\end{array}$ & $\begin{array}{c}\text { Total } \\
\text { leaf } \\
\text { area } \\
\left(\mathrm{mm}^{2}\right)\end{array}$ & $\begin{array}{l}\text { Shoot } \\
\text { dry } \\
\text { wt } \\
(\mathrm{mg})\end{array}$ \\
\hline Control & 0 & $163.10 \mathrm{a}$ & $38.61 \mathrm{a}$ & $0.85 \mathrm{a}$ & $190.48 \mathrm{a}$ & $110.13 \mathrm{a}$ & $9.41 \mathrm{a}$ \\
\hline \multirow[t]{3}{*}{ Decaying } & 6 & $153.44 \mathrm{ab}$ & $33.38 \mathrm{~b}$ & $0.79 \mathrm{~b}$ & $180.50 \mathrm{a}$ & $103.24 \mathrm{ab}$ & $9.14 \mathrm{ab}$ \\
\hline & 12 & $149.97 \mathrm{bc}$ & $32.17 \mathrm{~b}$ & $0.75 \mathrm{bc}$ & $153.66 \mathrm{~b}$ & $94.52 \mathrm{bc}$ & $8.82 \mathrm{~cd}$ \\
\hline & 18 & $148.68 \mathrm{bc}$ & $30.96 \mathrm{bc}$ & $0.69 \mathrm{de}$ & $151.58 \mathrm{~b}$ & $88.70 \mathrm{~cd}$ & 8.42 ef \\
\hline \multirow[t]{3}{*}{ Senesced } & 6 & $139.31 \mathrm{~cd}$ & $28.53 \mathrm{~cd}$ & $0.72 \mathrm{~cd}$ & $156.06 \mathrm{~b}$ & $79.34 \mathrm{de}$ & $8.88 \mathrm{bc}$ \\
\hline & 12 & $128.97 \mathrm{de}$ & $28.00 \mathrm{~d}$ & $0.66 \mathrm{e}$ & $141.21 \mathrm{bc}$ & $78.17 \mathrm{def}$ & $8.19 \mathrm{fg}$ \\
\hline & 18 & $124.59 \mathrm{e}$ & 24.10 ef & $0.58 \mathrm{f}$ & $135.29 \mathrm{~cd}$ & 70.71 ef & $7.83 \mathrm{hi}$ \\
\hline \multirow[t]{3}{*}{ Fresh } & 6 & $112.67 \mathrm{f}$ & $24.98 \mathrm{e}$ & $0.60 \mathrm{f}$ & $134.37 \mathrm{~cd}$ & $66.53 \mathrm{fg}$ & $8.57 \mathrm{de}$ \\
\hline & 12 & $101.87 \mathrm{fg}$ & $21.64 \mathrm{fg}$ & $0.47 \mathrm{~g}$ & $124.35 \mathrm{~d}$ & $60.68 \mathrm{gh}$ & $8.08 \mathrm{gh}$ \\
\hline & 18 & $96.47 \mathrm{~g}$ & $19.42 \mathrm{~g}$ & $0.40 \mathrm{~h}$ & $106.29 \mathrm{e}$ & $52.20 \mathrm{i}$ & $7.72 \mathrm{i}$ \\
\hline
\end{tabular}

Table 2. Cynodon dactylon root and shoot characteristics as affected by pine needle type (control, decaying, senesced, fresh) and the concentration of the incorporated tissue. Values are the means of four replications and means that differ significantly using Tukey-Kramer (HSD) at a probability level $P \leq 0.05$ are noted with different letters.

\begin{tabular}{|c|c|c|c|c|c|c|c|}
\hline $\begin{array}{l}\text { Pine } \\
\text { needle } \\
\text { type }\end{array}$ & $\begin{array}{c}\text { Pine } \\
\text { needle } \\
\text { tissue } \\
(\mathrm{g} / \mathrm{pot})\end{array}$ & $\begin{array}{l}\text { Total } \\
\text { root } \\
\text { length } \\
(\mathrm{mm})\end{array}$ & $\begin{array}{c}\text { Total } \\
\text { root } \\
\text { surface } \\
\left(\mathrm{mm}^{2}\right)\end{array}$ & $\begin{array}{l}\text { Root } \\
\text { dry } \\
\text { wt } \\
(\mathrm{mg})\end{array}$ & $\begin{array}{c}\text { Total } \\
\text { shoot } \\
\text { length } \\
(\mathrm{mm})\end{array}$ & $\begin{array}{l}\text { Total } \\
\text { leaf } \\
\text { area } \\
\left(\mathrm{mm}^{2}\right)\end{array}$ & $\begin{array}{l}\text { Shoot } \\
\text { dry } \\
\text { wt } \\
(\mathrm{mg})\end{array}$ \\
\hline Control & 0 & $61.27 \mathrm{a}$ & $8.59 \mathrm{a}$ & $0.32 \mathrm{a}$ & $70.33 \mathrm{a}$ & $43.43 \mathrm{a}$ & $0.86 \mathrm{a}$ \\
\hline \multirow[t]{3}{*}{ Decaying } & 6 & $53.89 \mathrm{ab}$ & $6.67 \mathrm{~b}$ & $0.29 \mathrm{ab}$ & $68.12 \mathrm{ab}$ & $36.55 \mathrm{ab}$ & $0.73 \mathrm{ab}$ \\
\hline & 12 & $52.86 \mathrm{ab}$ & $6.54 \mathrm{~b}$ & $0.29 \mathrm{ab}$ & $64.24 \mathrm{ab}$ & $30.39 \mathrm{bc}$ & $0.53 \mathrm{c}$ \\
\hline & 18 & $42.67 \mathrm{bc}$ & $5.01 \mathrm{cde}$ & $0.28 \mathrm{abc}$ & $58.42 \mathrm{bc}$ & $28.13 \mathrm{bcd}$ & $0.63 \mathrm{bc}$ \\
\hline \multirow[t]{3}{*}{ Senesced } & 6 & $51.41 \mathrm{ab}$ & $6.24 \mathrm{bc}$ & $0.27 \mathrm{abc}$ & $60.26 \mathrm{ab}$ & $25.13 \mathrm{cde}$ & $0.61 \mathrm{bc}$ \\
\hline & 12 & $50.92 \mathrm{ab}$ & $5.83 \mathrm{bcd}$ & $0.26 \mathrm{abc}$ & $60.02 \mathrm{~b}$ & $23.93 \mathrm{cde}$ & $0.57 \mathrm{bc}$ \\
\hline & 18 & $46.83 \mathrm{bc}$ & 5.54 bcde & $0.22 \mathrm{c}$ & $47.94 \mathrm{~cd}$ & 20.94 def & $0.45 \mathrm{c}$ \\
\hline \multirow[t]{3}{*}{ Fresh } & 6 & $34.94 \mathrm{c}$ & 5.41 bcde & $0.26 \mathrm{bc}$ & $49.04 \mathrm{~cd}$ & $21.20 \mathrm{def}$ & $0.6 \mathrm{~b} \mathrm{c}$ \\
\hline & 12 & $38.16 \mathrm{c}$ & $4.90 \mathrm{de}$ & $0.24 \mathrm{~b} \mathrm{c}$ & $49.05 \mathrm{~cd}$ & 18.16 ef & $0.24 \mathrm{~d}$ \\
\hline & 18 & $38.13 \mathrm{c}$ & $4.40 \mathrm{e}$ & $0.23 \mathrm{c}$ & $44.62 \mathrm{~d}$ & $13.23 \mathrm{f}$ & $0.48 \mathrm{c}$ \\
\hline
\end{tabular}

Table 3. Avena sativa root and shoot characteristics as affected by pine needle type (control, decaying, senesced, fresh) and the concentration of the incorporated tissue. Values are the means of four replications and means that differ significantly using Tukey-Kramer (HSD) at a probability level $P \leq 0.05$ are noted with different letters.

\begin{tabular}{|c|c|c|c|c|c|c|c|}
\hline $\begin{array}{l}\text { Pine } \\
\text { needle } \\
\text { type }\end{array}$ & $\begin{array}{c}\text { Pine } \\
\text { needle } \\
\text { tissue } \\
\text { (g/pot) }\end{array}$ & $\begin{array}{l}\text { Total } \\
\text { root } \\
\text { length } \\
(\mathrm{mm})\end{array}$ & $\begin{array}{c}\text { Total } \\
\text { root } \\
\text { surface } \\
\left(\mathrm{mm}^{2}\right)\end{array}$ & $\begin{array}{l}\text { Root } \\
\text { dry } \\
\text { wt } \\
(\mathrm{mg})\end{array}$ & $\begin{array}{l}\text { Total } \\
\text { shoot } \\
\text { length } \\
(\mathrm{mm})\end{array}$ & $\begin{array}{l}\text { Total } \\
\text { leaf } \\
\text { area } \\
\left(\mathrm{mm}^{2}\right)\end{array}$ & $\begin{array}{l}\text { Shoot } \\
\text { dry } \\
\text { wt } \\
\text { (mg) }\end{array}$ \\
\hline Control & 0 & $476.68 \mathrm{a}$ & $291.97 \mathrm{a}$ & $7.10 \mathrm{a}$ & $280.92 \mathrm{a}$ & $685.52 \mathrm{a}$ & $15.66 \mathrm{a}$ \\
\hline \multirow[t]{3}{*}{ Decaying } & 6 & $308.56 \mathrm{~b}$ & $176.39 \mathrm{~b}$ & $5.08 \mathrm{~b}$ & $222.62 \mathrm{~b}$ & $444.73 \mathrm{~b}$ & $12.21 \mathrm{~b}$ \\
\hline & 12 & $276.17 \mathrm{bc}$ & $172.92 \mathrm{~b}$ & $3.93 \mathrm{~cd}$ & $222.37 \mathrm{~b}$ & $400.97 \mathrm{bc}$ & $10.00 \mathrm{c}$ \\
\hline & 18 & $198.81 \mathrm{~d}$ & $113.17 \mathrm{cde}$ & $3.38 \mathrm{~d}$ & $189.39 \mathrm{bcd}$ & $391.33 \mathrm{bcd}$ & $9.35 \mathrm{~cd}$ \\
\hline \multirow[t]{3}{*}{ Senesced } & 6 & $238.33 \mathrm{~cd}$ & $146.11 \mathrm{bc}$ & $4.48 \mathrm{bc}$ & $212.50 \mathrm{~b}$ & $441.79 \mathrm{~b}$ & $9.43 \mathrm{~cd}$ \\
\hline & 12 & $193.89 \mathrm{~d}$ & $99.48 \mathrm{de}$ & $3.68 \mathrm{~d}$ & $205.92 \mathrm{bc}$ & $391.98 \mathrm{bc}$ & $9.02 \mathrm{~cd}$ \\
\hline & 18 & $191.58 \mathrm{~d}$ & 79.29 ef & $2.23 \mathrm{e}$ & 164.79 cde & $330.85 \mathrm{~d}$ & $7.89 \mathrm{e}$ \\
\hline \multirow[t]{3}{*}{ Fresh } & 6 & $197.49 \mathrm{~d}$ & $124.33 \mathrm{~cd}$ & $2.38 \mathrm{e}$ & $161.40 \mathrm{de}$ & $341.93 \mathrm{~cd}$ & $8.40 \mathrm{de}$ \\
\hline & 12 & $174.26 \mathrm{~d}$ & 75.16 ef & 1.75 ef & $140.46 \mathrm{e}$ & $265.37 \mathrm{e}$ & $6.37 \mathrm{f}$ \\
\hline & 18 & $96.90 \mathrm{e}$ & $47.97 \mathrm{f}$ & $1.40 \mathrm{f}$ & $97.25 \mathrm{f}$ & $170.51 \mathrm{f}$ & $4.14 \mathrm{~g}$ \\
\hline
\end{tabular}


Table 4. Festuca arundinacea radicle length as affected by a) extraction method, b) type of pine needles (decaying, senesced, fresh), and c) concentration of the extract. Values are the means of four replications. Numbers in parenthesis indicate the inhibition percentage compared to the control, while $\mathrm{I}_{50}$ values represent the necessary dose to inhibit radicle growth by $50 \%$ compared to the control as determined by log-probit analysis.

\begin{tabular}{|c|c|c|c|c|c|c|}
\hline \multirow{3}{*}{$\begin{array}{l}\text { Pine needle } \\
\text { extract concn } \\
\left(\mathrm{g} \cdot \mathrm{L}^{-1}\right)\end{array}$} & \multicolumn{6}{|c|}{ Radicle length (mm) } \\
\hline & \multicolumn{3}{|c|}{ Extract at room temperature } & \multicolumn{3}{|c|}{ Extract at $40^{\circ} \mathrm{C}$} \\
\hline & Decaying & Senesced & Fresh & Decaying & Senesced & Fresh \\
\hline 0.0 & $5.54(0.0)$ & $5.54(0.0)$ & $5.54(0.0)$ & $5.54(0.0)$ & $5.54(0.0)$ & $5.54(0.0)$ \\
\hline 1.5625 & $4.83(12.9)$ & $4.82(13.1)$ & $4.72(14.8)$ & $4.99(10.0)$ & $4.80(13.3)$ & $4.73(14.7)$ \\
\hline 3.125 & $4.52(18.4)$ & $4.69(15.4)$ & $4.65(16.1)$ & $4.63(16.5)$ & $4.67(15.7)$ & $4.44(20.0)$ \\
\hline 12.5 & $4.41(20.5)$ & $4.53(18.2)$ & $4.40(20.6)$ & $4.59(17.1)$ & $4.52(18.5)$ & $4.31(22.2)$ \\
\hline 50 & $4.21(24.0)$ & $4.10(26.1)$ & $3.48(37.2)$ & $4.33(21.9)$ & $4.06(26.7)$ & $3.19(42.4)$ \\
\hline 200 & $3.67(33.7)$ & $3.62(34.6)$ & $2.79(49.7)$ & $3.72(32.9)$ & $3.56(35.8)$ & $0.71(87.2)$ \\
\hline $\mathrm{I}_{50}$ & --- & --- & -- & --- & --- & 38.0 \\
\hline
\end{tabular}

Table 5. Cynodon dactylon radicle length as affected by a) extraction method, b) type of pine needles (decaying, senesced, fresh), and c) concentration of the extract. Values are the means of 4 replications. Numbers in parenthesis indicate the inhibition percentage compared to the control, while $\mathrm{I}_{50}$ values represent the necessary dose to inhibit radicle growth by $50 \%$ compared to the control as determined by log-probit analysis.

\begin{tabular}{|c|c|c|c|c|c|c|}
\hline \multirow{3}{*}{$\begin{array}{l}\text { Pine needle } \\
\text { extract concn } \\
\left(\mathrm{g} \cdot \mathrm{L}^{-1}\right)\end{array}$} & \multicolumn{6}{|c|}{ Radicle length (mm) } \\
\hline & \multicolumn{3}{|c|}{ Extract at room temperature } & \multicolumn{3}{|c|}{ Extract at $40^{\circ} \mathrm{C}$} \\
\hline & Decaying & Senesced & Fresh & Decaying & Senesced & Fresh \\
\hline 0.0 & $1.49(0.0)$ & $1.49(0.0)$ & $1.49(0.0)$ & $1.49(0.0)$ & $1.49(0.0)$ & $1.49(0.0)$ \\
\hline 1.5625 & $1.43(4.0)$ & $1.35(9.4)$ & $1.14(23.5)$ & $1.45(2.7)$ & $1.31(12.1)$ & $1.1(28.9)$ \\
\hline 3.125 & $1.40(6.0)$ & $1.32(11.4)$ & $0.94(36.9)$ & $1.41(5.4)$ & $1.25(16.1)$ & $0.67(55.0)$ \\
\hline 12.5 & $1.36(8.7)$ & $1.04(30.2)$ & $0.39(73.8)$ & $1.37(8.1)$ & $0.99(33.6)$ & $0.21(85.9)$ \\
\hline 50 & $1.28(14.1)$ & $0.85(43.0)$ & $0.19(87.3)$ & $1.32(11.4)$ & $0.51(65.8)$ & $0.00(100.0)$ \\
\hline 200 & $0.80(46.3)$ & $0.47(68.5)$ & $0.00(100,0)$ & $0.90(40.3)$ & $0.27(81.9)$ & $0.00(100.0)$ \\
\hline $\mathrm{I}_{50}$ & --- & --- & 65.0 & --- & 8.0 & 4.3 \\
\hline
\end{tabular}

Table 6. Lemna minor fresh weight as affected by a) extraction method, b) type of pine needles (decaying; senesced; fresh), and c) concentration of the extract. Values are the means of 4 replications. Numbers in parenthesis indicate the inhibition percentage compared to the control, while $I_{50}$ values represent the necessary dose to inhibit fresh weight by $50 \%$ compared to the control as determined by log-probit analysis.

\begin{tabular}{|c|c|c|c|c|c|c|}
\hline \multirow{3}{*}{$\begin{array}{l}\text { Pine needle } \\
\text { extract concn } \\
\left(\mathrm{g} \cdot \mathrm{L}^{-1}\right)\end{array}$} & \multicolumn{6}{|c|}{ Radicle length (mm) } \\
\hline & \multicolumn{3}{|c|}{ Extract at room temperature } & \multicolumn{3}{|c|}{ Extract at $40^{\circ} \mathrm{C}$} \\
\hline & Decaying & Senesced & Fresh & Decaying & Senesced & Fresh \\
\hline 0.0 & $200(0)$ & $200(0)$ & $200(0)$ & $200(0)$ & $200(0)$ & $200(0)$ \\
\hline 1.5625 & $210(-5)$ & $190(5)$ & $192(6)$ & $214(-7)$ & $176(12)$ & $122(39)$ \\
\hline 3.125 & $190(5)$ & $180(10)$ & $178(11)$ & $206(3)$ & $170(15)$ & $110(45)$ \\
\hline 12.5 & $184(8)$ & $168(14)$ & $150(25)$ & $190(5)$ & $164(18)$ & $86(67)$ \\
\hline 50 & $174(13)$ & $102(49)$ & $78(61)$ & $178(11)$ & $130(35)$ & $34(83)$ \\
\hline 200 & $166(17)$ & $70(65)$ & $50(75)$ & $170(15)$ & $94(53)$ & $12(94)$ \\
\hline $\mathrm{I}_{50}$ & --- & 152.5 & 71.0 & --- & --- & 14.8 \\
\hline
\end{tabular}

Table 7. Avena sativa radicle length as affected by a) extraction method, b) type of pine needles (decaying, senesced, fresh), and c) concentration of the extract. Values are the means of four replications. Numbers in parenthesis indicate the inhibition percentage compared to the control, while $\mathrm{I}_{50}$ values represent the necessary dose to inhibit radicle growth by $50 \%$ compared to the control as determined by log-probit analysis.

\begin{tabular}{|c|c|c|c|c|c|c|}
\hline \multirow{3}{*}{$\begin{array}{l}\text { Pine needle } \\
\text { extract concn } \\
\left(\mathrm{g} \cdot \mathrm{L}^{-1}\right)\end{array}$} & \multicolumn{6}{|c|}{ Radicle length (mm) } \\
\hline & \multicolumn{3}{|c|}{ Extract at room temperature } & \multicolumn{3}{|c|}{ Extract at $40^{\circ} \mathrm{C}$} \\
\hline & Decaying & Senesced & Fresh & Decaying & Senesced & Fresh \\
\hline 0.0 & $16.14(0.0)$ & $16.14(0.0)$ & $16.14(0.0)$ & $16.14(0.0)$ & $16.14(0.0)$ & $16.14(0.0)$ \\
\hline 1.5625 & $11.83(26.7)$ & $11.85(26.6)$ & $9.65(40.2)$ & $12.56(22.2)$ & $11.61(28.0)$ & $8.38(48.1)$ \\
\hline 3.125 & $10.83(32.9)$ & $10.78(33.2)$ & $7.68(52.4)$ & $11.79(27.0)$ & $10.06(37.7)$ & $7.48(53.7)$ \\
\hline 12.5 & $9.61(40.4)$ & $10.69(33.8)$ & $7.17(55.6)$ & $9.86(38.9)$ & $9.18(43.1)$ & $6.72(58.4)$ \\
\hline 50 & $8.97(44.4)$ & $8.75(45.8)$ & $5.28(67.3)$ & $9.16(43.2)$ & $7.72(52.2)$ & $2.35(85.4)$ \\
\hline 200 & $7.38(54.3)$ & $7.12(55.9)$ & $1.90(88.2)$ & $8.19(49.3)$ & $6.97(56.8)$ & $0(100.0)$ \\
\hline $\mathrm{I}_{50}$ & 78.0 & 80.5 & 8.5 & 125.0 & 47.0 & 5.6 \\
\hline
\end{tabular}

senesced pine needles. The extracts deriving from the decaying pine needles provided low inhibition of bermudagrass radicle elongation, indicating that the toxic substances were reduced as decomposition progressed. These results substantiated further the findings of Study I where bermudagrass was found to be more sensitive to pine needle phytotoxic substances compared to tall fescue. The difference in response between the two turfgrasses exhibited the species-specific inhibitory action of pine needle phytotoxic substances. These results are in accordance with the findings of Leather (1983), Rose et al. (1984), and Chung and Miller (1995), who demonstrated that the growth regulatory effects of allelochemicals possess species-specific action. The results of Study II confirmed that the greatest reduction of the studied turfgrasses species occurred when fresh pine needles were subjected to a warm-extraction procedure. It might be speculated that the warm extract of the pine needles may have enhanced the release of the phytotoxic substances compared with the room temperature extracts.

Study III: Pine needle extract effects on plantbiosensors. The two extraction treatments of the ground needle tissues affected the toxicity of the extracts according to the response of both plant bioindicators. The inhibition response of duckweed fresh weight differed between the two extraction methods, the extract concentration, and the type (fresh, senesced, and decaying) of the bioassayed tissues (Table 6). The room-temperature treatment exhibited less allelopathic potential compared with the warm-temperature treatment. The fresh-needle warm extraction caused a strong inhibition response, as the $I_{50}$ estimate (14.8 $\mathrm{g}$ of fresh pine needle extract/L) was about 4.8 times lower than inhibition at room temperature $\left(71.0 \mathrm{~g} \cdot \mathrm{L}^{-1}\right)$. In contrast, more inhibition was observed for the senesced pine needle tissue extract at room temperature $\left(152.5 \mathrm{~g} \cdot \mathrm{L}^{-1}\right)$ compared with extraction at $40{ }^{\circ} \mathrm{C}$. 
The phytotoxic effect of the pine needle extract on duckweed growth suggested that the inhibitory compounds belonged to substances that hindered photosynthesis, as duckweed can be effectively used as a bioassay for Photosystem II inhibitors and is especially sensitive to several phenolic compounds. However, duckweed is a peculiar aquatic plant, and the results of the bioassay should be extrapolated to terrestrial plants (Einhellig et al., 1985; Environmental Test Methods and Guidelines, 1996; Leather and Einhellig, 1985), and therefore the pine needle extracts were also tested on oat.

Oat was proved, as in Study I, extremely sensitive to all pine needle types. It was also noticed that the estimate $\mathrm{I}_{50}$ concerning duckweed inhibition was much higher compared with those received by the oat biotest (Tables 6 and 7). More specifically, oat exhibited a higher inhibitory response for the warm-temperature treatment, as the $50 \%$ of the radicle length reduction was estimated to be $\mathrm{I}_{50}=5.6$ and $47.0 \mathrm{~g} \cdot \mathrm{L}^{-1}$ in the fresh and the senesced pine needle extraction assays, respectively. In contrast, for the room-temperature treatment, the $I_{50}$ was $34.0 \%$ and $41.6 \%$ higher compared with the fresh and senesced needle extracts of the warm-temperature treatment, respectively (Table 7).

In the warm extract treatment there was a clear indication of increasing inhibition $\left(\mathrm{I}_{50}\right)$ of oat radicle length based on the pine needle type, which followed the sequence $\mathrm{D}<\mathrm{S}<\mathrm{F}$. In contrast, in the room-temperature treatment the sequence was $\mathrm{D}=\mathrm{S}<\mathrm{F}$. These results indicated that either different compounds were released by the different types of pine needles or that the concentration of the compounds was reduced as decomposition progressed. The reduction of the inhibitory action according to the progress of decomposition may be due either to the release of toxic substances from the decomposing tissues and/or to the decrease of the decomposition progress itself (Guenzi et al., 1967; Patrick et al., 1963).

The drastic effects of fresh pine needle aqueous extracts demonstrated the existence of compounds that may have substantial herbicidal activity. Such natural products, or their derivatives, could possess numerous advantages over current synthetic pesticides, namely the reduction of chemical pesticide environmental persistence and accumulation in conjunction with greater target selectivity and enhanced activity (Leather and Einhellig, 1985).

The study clearly demonstrated that watersoluble inhibitory substances were present within the pine needle tissues. The inhibitory substances have the potential to significantly affect turfgrass growth either by leaching from the tree canopies towards the turf sward during rain or by the shearing and grounding of the fallen pine needles during mowing of the turf. Further research is needed to categorize other turfgrass species and varieties in terms of their response to pine tissue inhibitory compounds in order to provide a useful tool to turf managers. In addition, the variable inhibition exerted by different turf species to the pine needle compounds necessitates their testing as a potential natural herbicide resource (Putnam and Duke, 1978). In such case, of special interest would be the determination of the actual constituents that cause growth inhibition in turfgrasses.

\section{Literature Cited}

Brede, A.D. 1991. Field apparatus for testing allelopathy of annual bluegrass on creeping bentgrass. Crop Sci. 31:1372-1374.

Buta, J.G., D.W. Spaulding, and A.N. Reed. 1987. Differential growth responses of fractionated turfgrass seed leachates. HortScience 22(6):1317-1319.

Chung, ILL-M. and D.A. Miller. 1995. Natural herbicide potential of alfalfa residue on selected weed species. Agron. J. 87:920-925.

Einhellig, F.A., G.R. Leather, and L.L. Hobbs. 1985. Use of Lemna minor L. as a bioassay in allelopathy. J. Chem. Ecol. 11:65-72.

Finney, D.J. 1962. Probit analysis. Cambridge: University Press, Cambridge, U.K.

Finney, D.J. 1978. Statistical method in biological assay. 3 ed. Charles Griffin and Co. Ltd., London, U.K.

Grainge, M., and S. Ahmed. 1988. Handbook of plants with pest-control properties. Wiley, New York.

Guenzi, W.D., T.M. McCalla, and F.A. Norstadt. 1967. Presence and persistence of phytotoxic substances in wheat, oat and sorghum residues. Agron. J. 59:163-165.

Kokko, E.G., K.M. Volkmar, B.E. Gowen, and T. Entz. 1993. Determination of total root surface area in soil core samples by image analysis. Soil Tillage Res. 26:33-43.

Leather, G.R. 1983. Sunflowers (Helianthus annuus) are allelopathic to weeds. Weed Sci. 31:37-42.
Leather, G.R. and F.A. Einhellig. 1985. Mechanisms of allelopathic action in bioassay, p. 197-205. In: A.C. Tompson (ed.). The chemistry of allelopathy. Amer. Chem. Soc. Symp. Ser. 268.

Lickfeldt, D.W., T.B. Voigt, B.E. Branham, and T.W. Fermanian. 2001. Evaluation of allelopathy in cool season turfgrass species. Intl. Turfgrass Soc. Res. J. 9:1013-1018.

Luu, K.T., A.G. Matches, C.J. Nelson, E.J. Peters and G.B Garner. 1989. Characterization of the inhibitory substances of tall fescue on birdsfoot trefoil. Crop Sci. 29:407-412.

Olofsdotter, M., D. Navarez, and K. Moody. 1995. Allelopathic potential in rice (Oryza sativa L.) germplasm. Ann. Appl. Biol. 127:543-560.

Pallant, E. and S.J. Riha. 1990. Surface soil acidification under red pine and norway spruce. Soil Sci. Soc. Amer. J. 54:1124-1130.

Patrick, Z.A., T.A. Toussoun, and W.C. Snyder. 1963. Phytotoxic substances in arable soils associated with decomposition of plant residue. Phytopathology 53:152-161.

Peters, E.J. 1968. Toxicity of tall fescue to rape and birdsfoot trefoil seeds and seedlings. Crop Sci. 8:650-653.

Peterson, G.S., M.A. Kandil, and M.D. Abdallah. 1989. Isolation and characterization of biological activity compounds from some plant extracts. Pesticides Sci. 25:337-342.

Putnam, A.R. and W.B. Duke. 1978. Allelopathy in agroecosystems. Annu. Rev. Phytopathol. $16: 431-451$

Rice, E.L. 1984. Allelopathy. Academic Press, Orlando, Fla.

Rose, S.J., O.C. Burnside, J.E. Specht, and B.A. Swisher. 1984. Competition and allelopathy between soybean and weeds. Agron. J. 76:523-524.

Smith, A.E. 1989. Interference with loblolly pine (Pinus taeda) seedling growth by three grass species. Weed Technol. 3:696-698.

Wilt, F.M., G.C. Miller, and R.L. Everett. 1993a. Measurement of monoterpene hydrocarbon levels in vapor phase surrounding single-leaf pinyon (Pinus monophylla Torr. \& Frem.: Pinaceae) understory litter. J. Chem. Ecol. 19(7): 1417-1428.

U.S. Environmental Protection Agency. 1996. Environmental test methods and guidelinesAquatic plant toxicity using Lemna spp. In: U.S. Environmental Protection Agency Prevention, Pesticides and toxic Substances (7101). EPA 712-C-96-156, April.

Wilt, F.M., G.C. Miller, R.L. Everett, and M. Hackett. 1993b. Monoterpene concentrations in fresh, senesced, and decaying foliage of single-leaf pinyon (Pinus monophylla Torr. \& Frem.: Pinaceae) from the western Great Basin. J. Chem. Ecol. 19(2): 185-194. 